\author{
S.A. Agayeva ${ }^{1}$, E.I. Kaliyeva ${ }^{1}$, A.K. Kitibayeva ${ }^{2}$ \\ ${ }^{1}$ Yessenov University, Aktau, Kazakhstan; \\ ${ }^{2}$ Ye. A. Buketov Karaganda State University, Kazakhstan \\ (E-mail: sona.agayeva@yu.edu.kz)
}

\title{
Research and methodology competency through the different contexts.
}

\begin{abstract}
The present article reveals the concept of research and methodology competency integrating it through different worldviews and timelines. A theoretical analysis of pedagogues and psychologists' works is applied. In addition, with the purpose of deepening the conceptual problem, philosophers' literature is used to emphasize the initial idea of the research and methodology phenomenon through various paradigms and discourse. Five educational paradigms are analyzed, and research methods prevailing are revealed to compare the core idea of the research and methodology competency concept at that period. Qualitative and quantitative research methods, the researcher's position and participants' background are taken into consideration while analyzing the research and methodology competency phenomenon. The literature theoretical review combines different periodization starting from 1957 to 2019. The latest research is presented to highlight shifting of the research focus to a student-centered paradigm and its connection to defining the concept of the research and methodology concept. In conclusion, a brief description of the five worldviews is presented based on more than ten literature sources.
\end{abstract}

Keywords: research and methodology competency, mixed methods, research methodology, research methodology concept, educational paradigm, research competency, research methods, qualitative method, quantitative methods.

\section{Introduction}

The problem of research and methodology competency in Kazakhstan is currently at its initial stage of studying. In the present article, we have chosen the concept of research and methodology competency to be defined and carefully studied from the different aspects of authors' views. The second half of the twentieth century has been featuredby the knowledge acquisition via education at different level schools, which has been losing its relevance and value at present times.

The main reason that affects this transfer is accessibility to information. Widely spread massive informatization and the active development of the communication means have revealednaturally this manifestation. The modern world is characterized by the contradiction of the role of knowledge in the technical, scientific, and social processes. Moreover, new qualities concerning socializing are beginning to become the absolute value of education.

A self-reflecting and developing personality, capable of searching, processing, applying, analyzing, synthesizing and evaluating the knowledge in practice, gradually replaced common learning the information. Changing the value basis of education makes it necessary to introduce a new concept that would reflect the individual's ability to solve emerging problems that require the availability of knowledge, experience and their transformation according to skills and individual characteristics. This concept is denoted as a competency, that is, the ability of a person to deal with emerging tasks, due to the specifics of practical activity.

Different competencies are currently studied, such as communicative, intellectual, informational, technological competencies and others. However, we consider the research and methodology competency to be underevaluatedin Kazakhstan reality, and suggest the present competency to be theoretically investigated. The present article studies the research and methodology competency as the concept in pedagogical, psychological works. fully.

In addition, philosophers' literary works are analyzed to have the concept studied deeper and more care-

Research and methodology competency possesses the object of the study, and the object is available at different points of view. Research and methodology competency involves the knowledge, capabilities and skills that are necessary for establishing various empirical/experimental investigations according to the current educational standards. 


\section{Main Part}

Wagner \& Maree examined the curricula on research methodology at South African universities. The analysis of the curricula implies that the research methods taught were of the positivism. This positivist paradigm is popular and common in universities worldwide [1]. The research paradigm tends to analyze, confirm and predict law-like patterns of behaviour, and is widely used in research aiming at testing theories or hypotheses [2].(Educational research paradigms: From positivism to multiparadigmatic Taylor Medina)

The positivist paradigmcould beespeciallyapplicable in STEM (Science, Technologies, Engineering and Math) education and, partly, in the humanities, e.g. Anthropology, Archaeology, Economics, Geography, History, Law, Linguistics, Politics, Psychology or Sociology, where large series of analytical results are involved.

Creswell implies the focus of the paradigm on the objectivity of the research process. Moreover, he highlights that the data in the research are more descriptive, i.e. using words prevails figures and numbers [3;35]. The positivist paradigm frequently applies quantitative methodology; adopting experimental methods like experimental/focus and control groups and calculation of pre- and post-experimental analysis. The researcher is external to the site and controlling the research process.

Cronbach assumes that major traditions are the experimental and differential traditions associated with rather independent research methods [4]. The development of research methodology competency must take these traditions into consideration in order to prepare the students appropriately for all the requirements of any research.

The research methodology under the governance of the positivist paradigm leads to prevailing of the representative form: the reports are written objectively using the construction of passive voice, the genderneutral third-person pronoun 'it', and the past tense and aspect.

Thus, the research methodology competency means learning about methods for planning investigations, collecting and processing data, analyzing the language of the research using appropriate and correct grammar forms and structures.

The constructivist paradigm in research has the belief that individual understanding of the world is of high importance. The constructivist worldview depicts the idea that the learning process does not happen from the traditional method of educating.

However, to the constructivist, learning occurs only when the learner discovers the knowledge through the spirit of experimentation and doing [5].Here, the focus in the research is on subjective meanings. Again, data remains descriptive, but now the researcher is actively involved in this description [6;54]. Staying deeply in the research, the researcher relies on experiment participants' feelings, emotions, opinions and expressions. Thus, the competency in the constructivist paradigm research is on data collecting, interviewing and analyzing the participants' behaviour.

At the beginning of the $21^{\text {st }}$ century, the core of the research methodology in the social sciences shifts to some transformations [7] taking place in society [8; 23]. Tashakkori and Teddlie during 2005-2010 had been conducting the research on the effects of these changes on higher education. They came to the conclusion that research methodology needs to integrate qualitative and quantitative, and emphasized the usefulness of mixed methods in research $[9 ; 67]$.

Muller points out that a researcher should not simply deliver a critical perspective and then expect the world to change on the strength of these 'new insights'. People are not immediately ready for changes for many reasons, such as not wanting to admit to 'uncomfortable realities' [10; 137]. The steps to changing large parts of education such as processes or systems might face resistance. In their article, Wagner \& Maree find several constituent parts to improve research methodology skills [1]. These parts consist of training undergraduate students to become good consumers instead of practitioners of research $[11 ; 71]$, forging research partnerships between higher education institutions, industry, and the state [12], and transforming curricula to the Mode 2 model of knowledge production where students are shaped into innovators [13; 89], and so on.

Thus, the sample in the investigation of Maree \& Wagner comprises three courses that concentrate on the research designs and data collection or statistical analysis methods. However, many common basic concepts (e.g., the concepts known as scale, variable, variance and covariance), and common basic principles (e.g., the principles of hypothesis testing and of standardization) [1] should guide the ways of meeting different requirements. 
The courses are the result of dividing the entire teaching process into interdependent parts. Some courses reveal basic ideas and fundamental concepts while the other courses provide sophisticated methods and applications. Moreover, the dependency among the courses should guarantee systematic knowledge growth.

As a response to constructivist paradigm, where the participants are socially active individuals, the transformative paradigm arose at the end of the XX century. The authors of the transformative worldview emphasized the necessity of the marginalized individuals including ethnic and racial minorities, sexual minorities such as transgender people, gays and lesbians, and those who are not sure about their gender identity; feminists, persons with limited legal capacities, etc.

Through the transformative paradigm, the researchers allow different type minorities to express their viewpoints. The participants become open to the culture and society raising their self-consciousness at the same time. In addition, the emphasis of the research and methodology competency shifts to advocating skills, psychological awareness and mindedness, while interviewing, collecting and processing data are still necessary competences.

The fourth worldview that contrasts post positivist and positivist is pragmatic; pragmatism as a worldview arises out of actions, situations, and consequences rather than antecedent conditions [14; 134]. Here, methodology and application are not of high significance.

On the contrary, researchers highlight the research problem/hypothesis and use all approaches for problem investigation. The research focuses on various approaches to study implicitly and explicitly the understanding of the problem.

According to Cherryholmes, Morgan, and Creswell, pragmatic paradigm research methodology provides a freedom of choice for researchers $[15,16,14]$. Consequently, researchers could conduct needs and interests analysis, and, following the results of the analysis, they apply the methods, techniques, and procedures of research that meet these needs and purposes [16]. Moreover, through pragmatic worldview, researchers usea variety of approaches for collecting and processing data rather than adjusting to only one way (e.g., quantitative or qualitative).

The pragmatist research and methodology competencystudies what and how to research based on the intended consequences. The researchers who apply both types of methods, qualitative and quantitative, need to justify a purpose for mixing the methods, a rationale for the reasons why quantitative and qualitative data need to be mixed in the first place.

The investigators of the pragmatic paradigmconsider that we need to stop asking questions about physical reality and the laws of nature [15]. «They would simply like to change the subject» [17; 14]. Thus, as for the pragmatic research methodology, multiple methods, different worldviews, and different assumptions, as well as different forms of data collection and analysis are used. Hence, the research and methodology competency includes data collecting and processing, and needs analysis as the most important competences and skills.

In 1991, Roy José DeCarvalho brings the humanistic educational paradigm back to life. Before that time, the paradigm idea of Abraham Maslow and Carl Rogers forced the humanistic movement in American psychology in 1960s. DeCarvalho reviews Maslow's concept of intrinsic learning and Rogers' student-centered education as the revolutionary ideas in education [18], and finds that the humanistic paradigm has been implemented in the sphere of education within the period of 1960 until 1990. In the research, the interpretive paradigm as the subdivision of the humanistic worldview takes place.

Theinterpretive paradigm in educational research was established in 1970s, as the effectof anthropological attemptsto understand other cultures from the inside. The researchers were completely involved in the culture being studied [18]. Participant observation, informal interviews, and establishing ethically sound relationships were used as the parts of the research methodology. The aim of the conducted researchwas to depict authentic cultural profiles of the other person. From the educational point of view, the interpretive paradigm leads togaining rich understanding of the world experiences.

Due to the vague objectivity of the research, taking informality and subjective observation into consideration, in 1989 Guba and Lincoln invented trustworthiness and authenticity standards such as credibility, dependability, transferability, and confirmability [19]. Credibility reveals the ability of the researcher to be immersed in the field for a long period that is enough to conduct the research, and checking the interpretations with the research participants. Dependability is connected with the type of inquiry of the researcher, e.g. were the questions of the interview open-ended or did these questions assume the 'correct' answer. Transferability considers the research content: are the social processes descripted in the way that allows the 
future readers to compare with their own context. Confirmability ensures the process of data- and factchecking.

DeCarvalho emphasises the significance of the researcher's subjectivity in the process of interpretation [19], andthe ability of asking peculiar questions during the whole process of the research starting from planning stage till the conclusive part of the research. These peculiar questions are aimed to gather the information about participants' background, their ethnic, national or racial identity, informants' gender identity, their political, social preferences, and needs and interests.

Thus, self-reflection, and reflection partnerships and practitioners started existing as the core competences for the research methodology. These are the very first steps to the new research methodology competency understating and the new approach, overall: the student-centered educational paradigm, which is currently prevailing.

The criteria and policies of the interpretive paradigm have a strong discordance with the standards of the critical paradigm. That has definitely changed the research methodology and, consequently, its competency concept and parts.

The critical research paradigm enables the researcher to practice 'deep democracy' [20]including analyzing and transforming socially unfair social beliefs, policies or structures. Here, the primary focus is to identify and solve the issues connected with socially excluded sectors, loss of cultural identity amongst ethnic minorities.

The critical paradigm research methodology comprises the process of writing as inquiry integrating it with the critical dimension and becomes a means of critical analysis.

The researcher improves critical consciousness and develops an image of a better society. The process of constructing the vision of the societyis established individually or, in most cases, in collaboration with less empowered participants, whereas the researcher acts as a facilitator [2]. The researcher's role is one of advocacy, the same as in transformative paradigm, with the purpose of establishing a more, fair and sustainable society.

The conscious awareness is highlighted in the research methodology competency, andthe researcher's critical thinking is introduced that stimulates creative thinking and assessment to become more studentcentred.

The research methodology competency can be evaluated through the prism of the competences, capacities and skills that are very different from those of the positivist paradigm but which are similar to the standards of the interpretive paradigm. Demonstrating critical self-awareness, self-consciousness and critical understanding of the social process are of high importance.

The research methodology competency applied in the critical paradigminvolves action research and leads to the researcher's evolving praxis. In addition, the competency addresses the capacities to elicit critical understanding and awareness, and self-consciousness in readers. The style ofwriting and presenting changes and shifts the focus from descriptive to critical in order to influence on the readers, with continuing in the postmodern worldview.

The postmodern paradigm remains one of the most challenging with new understanding of the research and methodology for educational researchers. The researchrevives the phenomenon of representation andgives a new conceptual idea to its $[21 ; 112]$. The representation in postmodern philosophy indicates that person's ideas, opinions, feelings and emotionsare not explicitly accessible to the world outside. An individual is not able to render his/her feelings and ideas to another person, and the possible solution to transfer them is to 'represent' the thoughts and emotions through the communication.

From the research point of view, the scientific observations are full of theory whether carried out using common observation or equipment such as video- or photocameras, microphones, voice recorders or OHP (over-head projectors) [2].

Thus, scientific knowledge isdependent and open to changes, challenges and amendments. The knowledge continues to evolve, integrating with various concepts and considering contradictory facts.

Pluralistic visionof the postmodern paradigm provides the ability to integratescience and the research methodology with other disciplines such as The Arts. The Arts-based research methodology has been revived, adding new ways of representation:

- literary genres such as impressionist writing, storytelling, autobiography, poetry, drama, role-play and fiction [22; 53], and

- visual imagery such as filming, painting, dance and photography. 
Furthermore, the Arts-based research methodologyacts inadditional modes of reasoning. Exceptdeductive, propositional, and analytic logic, the research methodology represents inductive approach, metaphorical and dialectical thinking.

Here, the research methodology competency requiresupgraded quality standards for regulating the conducting of the research. These qualitiesservethe purpose of engaging common readers and making the understanding of the research possible. Creative writing with the combination of critical thinking causes resonance with the readers' experiences. Thus, the research methodology competency consists of the ability to write in a way isunderstandable, realistic, and believable.

In the latest research, in 2019, a competency-based research methodology has been implemented as a training tool to teach undergraduate students for further research activity [23]. In this research, four core competences were identified as parts of research methodology competency: research related knowledge, research related skills, behavior and communication competence, and ethics and human subject protection.

According to Patra and Maroof Khan, specialists have to obtain certain abilities such as communicating with community members, interacting with peers, conducting in a professional manner [23]. Demonstrating ethics and human rights protection focus, ensuring confidentiality and privacy are of high importance. The learner-centered paradigm demands communicative competence, humanistic approach to conducting research, different interaction patterns among the community members including researcher and participants.

\section{Conclusion}

The rapid globalization of the world and stable shifting current educational paradigm from teachercentered to learner-centered makes competency-based approach relevant to the social world in which we live. The research and methodology competency needs to be discussed through the prism of these new directions and forged as a completely new way of acting in this world.

Research methodology competency is considered to obtain a significantly high degree of complexity for the effect study. Through different paradigms, the research methodology competency is examined in different contexts.

For the positivist and the post-positivist worldview, the important constituent parts of the research methodology competency are planning skills, analyzing and collecting data. The ontology of the positivist and post-positivist paradigm research methodology is realistic, the research is objective. The methodology is quantitative, and the quality standards are validity and reliability, and the research methodology competency requires the data to be figured out and analyzed using statistics.

For the constructive philosophy, a slight transformation to the student-centered approach is noticed. The research methodology competency includes communicative competence to establish communication with informants, and interviewing skills for making an emotional description available as well. At the same time, data analysisis used, again in a descriptive way. As the behavior of the participants is the primary focus in the research, the methodology competency consists of observation skills and the ability to monitor the process of the experiment.

The transformative paradigm continues the policy of observation in the research methodology, but shifts the focus from common observation and decodingto advocating skills, and developing and raising psychological awareness of both the researcher and the participants. The methodology is qualitative, and the research methodology competency starts the process of developing critical thinking which will later find expression in critical research methodology.

The pragmatic worldview applies mixed methods of the research: quantitative and qualitative, and here, the most significant competency is observation, and data collecting, processing and analyzing as well. The methodology is not important in pragmatic worldview, which shapes the mix of techniques, methods and tools.

While implementing more recent paradigms, alternative representation means become available. For the interpretive paradigm, personal opinions are prescribed, including the researcher and participants' perspectives. Narrative using the first person structures make outcomes be available to depict a certain viewpoint, demonstrating how the author has expressed meaning and ensuring sufficient details necessary for understating the context.

When applying the critical philosophy, the primary focus of the researcher is to empower 'weaker' voices, providing fairness, equity and justice. Interpretive and critical research methodology includes using a wide range of personal pronouns, active and passive voice, and various tenses and aspects. The preferences depend on the context of the research and the aim of the researcher. Moreover, these preferences and necessi- 
ty of the appropriate style lead to establishing a new skill through the research methodology competency: academic writing.

The Arts-based research methodology enlarges the skills, capacities and competences influencing on the educative and literary quality of the researcher's writing. Contrasting the exactly established structural parallelism of academic writing, the creative writing is a competence that engages the informants and readers of the research conducted.

The transfer to the learner-centered approach revealsvaluable interaction patterns, and communicative and behavior competence integrating them with ethics and human right protecting skills such as advocacy. Establishing good rapport in the learner-centered worldview is of high importance as well.

\section{References}

1 Wagner, C. \& Maree, D. (2007). Teaching research methodology: Implications for psychology on the road ahead. South African Journal of Psychology, Vol. 37(1), 121-134. DOI: 10.1177/008124630703700109

2 Taylor, P \& Medina, M. (2013). Educational research paradigms: From positivism to multiparadigmatic. International Journal of Meaning Centre education, Vol. 1(1), 1-16. DOI: 10.13140/2.1.3542.0805

3 Creswell, J.W. (2008). Educational research: Planning, conducting, and evaluating quantitative and qualitative research (3rd ed.). Upper Saddle River, NJ: Pearson Education, Inc.

4 Cronbach, L.J. (1957). The two disciplines of scientific psychology. American Psychologist, Vol. 12(11), 671-684.

5 Kalender, S. (2007). Applying the subject «cell» through constructivist approach during science lessons and the teacher's view. Journal of Environmental \& Science Education, Vol. 2(1), 3-13.

6 Creswell, J.W. (2014). Research Design: Qualitative, Quantitative and Mixed Methods Approaches (4th ed.). Thousand Oaks, CA: Sage.

7 Brew, A. (2003) Teaching and Research: New relationships and their implications for inquiry-based teaching and learning in higher education. Higher Education Research \& Development, Vol. 22(1), 3-18. DOI: 10.1080/0729436032000056571

8 Tashakkori, A. \& Teddlie, C. (2003). Handbook of Mixed Methods in Social \& Behavioral Research. Thousand Oaks: Sage.

9 Tashakkori, A. \& Teddlie, C. (2010).SAGE handbook of mixed methods in social \& behavioral research. Thousand Oaks, CA: SAGE Publications, Inc. DOI: 10.4135/9781506335193

10 Muller, J. (2000). Reclaiming knowledge: Social theory, curriculum and education policy. London: Routledge.

11 Porte, G. K. (2002). Appraising research in second language learning: A practical approach to critical analysis of quantitative research. Amsterdam: Benjamins.

12 Kraak, A. (1997). Globalisation, changes in knowledge production, and the transformation of higher education. In N. Cloete, J. Muller, M.W. Makgoba, \& D. Ekong (Eds.). Knowledge, identity and curriculum transformation in Africa, 51-78. Cape Town: Maskew Miller Longman.

13 Gibbons, M., Limoges, C., Nowotny, H., Schwartzman, S., Scott, P., \& Trow, M. (1994). The new production of knowledge: The dynamics of science and research in contemporary societies. ThousandOaks, CA: Sage.

14 Creswell, J.W. (2014). Research Design: Qualitative, Quantitative and Mixed Methods Approaches (4th ed.). ThousandOaks, CA: Sage.

15 Cherryholmes, C.H. (1992). Notes on Pragmatism and Scientific Realism. Educational Researcher, Vol. 21(6), 13-17. DOI: 10.3102/0013189X021006013

16 Morgan, D.L. (2007). Paradigms Lost and Pragmatism Regained: Methodological Implications of Combining Qualitative and Quantitative Methods. Journal of Mixed Methods Research, Vol. 1(1), 48-76. DOI: 10.1177/2345678906292462

17 RoRTy, R. (1982). Consequences of Pragmatism: Essays 1972-1980. Minneapolis: University of Minnesota Press.

18 DeCarvalho, R.J. (1991). The humanistic paradigm in education. The Humanistic Psychologist, Vol.19(1), 88-104. DOI: 10.1080/08873267.1991.9986754

19 Guba, E.G., Lincoln, Y.S. (1982). Epistemological and methodological bases of naturalistic inquiry. Educational Communication and Technology Journal. Vol. 30(1), 233-252. DOI: 10.1007/BF02765185

20 Kincheloe, J. L., \& McLaren, P. (2005). Rethinking Critical Theory and Qualitative Research. In N.K. Denzin \& Y.S. Lincoln (Eds.), The Sage handbook of qualitative research. 303-342. Sage Publications Ltd.

21 Denzin, N.K., \& Lincoln, Y.S. (Eds.). (2005). The Sage handbook of qualitative research (3rd ed.). Sage Publications Ltd.

22 Knowles, J. G., \& Cole, A. L. (2008).Handbook of the arts in qualitative research: Perspectives, methodologies, examples, and issues. ThousandOaks, CA: SAGE Publications, Inc. doi: 10.4135/9781452226545

23 Patra, S., \& Khan, A.M. (2019). Development and implementation of a competency-based module for teaching research methodology to medical undergraduates. Journal of education and health promotion, Vol. 8,(1), 164-175. https://doi.org/10.4103/jehp.jehp_133_19 


\title{
С.А. Агаева, Э.И. Калиева, А.К. Китибаева
}

\section{Түрлі контекст ғылыми-әдістемелік құзыреттілік}

\begin{abstract}
Мақалада ғылыми-әдістемелік құзыреттілік тұжырымдамасы әртүрлі дүниетанымдар мен уақыт шеңберлері арқылы қарастырылған. Педагогикалық және психологиялық әдебиеттердің теориялық талдауы берілген. Осындай талдаумен қатар, ғылыми-әдістемелік құбылыстың бастапқы түсінігін қарастыру және мәселе ұғымын терең талдау мақсатында философиялық ғылыми еңбектер де талқыланған. Мақалада ғылыми-әдістемелік құзыреттілік тұжырымдамасы туралы негізгі идеяларды салыстыруға арналған зерттеу әдістері басымдықтарының бес білім беру парадигмасы қарастырылған. Зерттеудің сандық және сапалық әдістеріне қабылданған тәсілдің құзыреттілігі, зерттеушінің ұстанымы мен зерттеуге қатысушылардың шығу тегіне талдау назарға алынған. Теориялық әдебиеттерге шолу 1957 жылдан 2019 жылға дейінгі кезеңдерді қамтиды. Соңғы зерттеулер ғылымиәдістемелік құзыреттіліктің фокустық деңгейінің окушыға бағытталған білім беру тәсіліне ауысуын, сондай-ақ оның ғылыми-әдістемелік құзыреттілік тұжырымдамасының өзгеруімен байланысын нақтылау үшін ұсынылған. Қорытынды бөлімде оннан астам әдеби көзге сілтеме жасай отырып, бес білім беру дүниетанымдарының қысқаша сипаттамасы келтірілген.
\end{abstract}

Кілт сөздер: ғылыми-әдістемелік құзыреттілік, аралас әдіс, зерттеу әдістемесі, ғылыми-әдістемелік құзыреттілік түсінігі, білім беру парадигмасы, зерттеу құзыреттілігі, зерттеу әдістері, сандық әдіс, сапалық әдіс.

\section{С.А. Агаева, Э.И. Калиева, А.К. Китибаева}

\section{Научно-методическая компетентность в различных контекстах}

В статье рассмотрено понятие научно-методической компетентности сквозь призму различных мировоззрений и временных рамок. Приведен теоретический анализ педагогической и психологической литературы. Наряду с этим, изучены также философские научные работы, а также пять образовательных парадигм с точки зрения преобладающих методов исследования для сравнения ключевых идей о понятии научно-методической компетентности. При анализе компетентности приняты во внимание количественный и качественный методы исследования, позиция исследователя и происхождение участников исследования. Теоретический обзор литературы объединяет периоды с 1957 по 2019 годы. Представлены последние исследования для уточнения перехода фокуса научно-методической компетентности при студенто-ориентированном образовательном подходе, а также в связи с изменением понятия научно-методической компетентности. В заключении предложено краткое описание пяти образовательных мировоззрений со ссылкой на более чем десять литературных источников.

Ключевые слова: научно-методическая компетентность, смешанный метод, методология исследования, понятие научно-методической компетентности, образовательная парадигма, исследовательская компетентность, методы исследования, количественный метод, качественный метод. 